\author{
Viktor Tsekhanovych \\ Postgraduate Student \\ Department of Economic Theory, Marketing and Entrepreneurship \\ State University Luhansk Taras Shevchenko National University, Starobilsk, Ukraine \\ E-mail: victor134@ukr.net \\ ORCID: https://orcid.org/0000-0001-7199-8558
}

\title{
The role of Euroregions in integration processes
}

\begin{abstract}
Modern international relations are characterized by integration processes, among which Euroregional cooperation plays an important role. Euroregional cooperation as an element of state policy today occupies a rather important place both in the system of priorities of socio-economic development and in the direction of European integration of Ukraine. Such a policy, on the one hand, is aimed at ensuring the comprehensive development of the regions, and on the other hand, at preserving the territorial integrity of the state. It is implemented on the basis of jointly developed programs of trade, economic, scientific, technical and cultural cooperation. Active regional development is considered as one of the elements of the pan-European system of priorities, which corresponds to the fundamental integration of states through the integration of Regions. Such activities involve accelerating the socio-economic development of euroregions, personnel and infrastructure training of Regions and the country as a whole to deepen cooperation with the EU, and accelerating European integration processes. Euroregions allow their participants to quickly solve common problems, create flexible, joint economic structures, establish cross-border trade, tourism, and expand cooperation in cultural, social, environmental and other fields. Their functioning is based on the principles of local self-government and cross-border cooperation. The activation of Euroregional ties in the context of integration and the creation of various forms of cooperation have positive results for the regions and for Ukraine as a whole. This makes it possible to modernize economic processes, attract foreign investment and new technologies, and create new jobs, which will lead to competition between products and the region. The integration processes that have recently been observed in Euroregions, in addition to traditional cross-border cooperation, can be distinguished as innovative, which include Euro-regional and cross-border clusters, business incubators, technology parks. All this leads to increased competitiveness of the regions, which leads to increased effective use of the region's potential.
\end{abstract}

DOI: https://doi.org/10.30525/2500-946X/2021-1-4

\section{Introduction}

Certain processes occurring in the economy and society characterize economic development. One of them is a transformation in the direction of forming a post-industrial society, the priority of which is a person with his or her creative and intellectual potential and the conditions of the person's life. In turn, ensuring the necessary freedom, meeting various needs, realizing the potential of the individual, creating its living space, which cannot be limited to the framework of one country, as well as eliminating signs of periphery, require the development of euroregional cooperation based on its simple and complex organizational forms.

Intensive integration processes characterize the current stage of globalization of the world economy, where one of the main places belongs to regional cooperation. Considering the European integration direction of Ukraine it should be noted that euroregional cooperation is the priority of socioeconomic development of the country and an integral part of the state policy of our time.

Deepening euroregional cooperation Ukraine and the EU will open up great opportunities for action sightings of activities in border regions, more than efficient use of resource potential, it will help increase competitiveness of
Keywords

Euroregional cooperation, euroregion, development, transnationalization

JEL: R10, R11 these regions and the country as a whole. So, the chosen research topic in the context of deepening integration processes, signing an expanded free trade area with the EU and further cooperation is relevant and requires further research.

The relevance of this study lies in the fact that globalization and the interactive level of international relations in the modern world require the search for new forms and methods of cooperation between states, and precisely euroregions can become such a form of cooperation for Ukraine, because today they are Ukrainian the border territories are not sufficiently realizing the opportunities for euroregional cooperation.

A theoretical and methodological analysis of this issue makes it possible to effectively study the essence and necessity functioning of euroregions in the context of the implementation of national interests

\section{Mechanisms of integration processes of Euroregions (case of the Carpathian Euroregion)}

Integration processes within Euroregions promote the free movement of goods, services, capital, and people. Here, integration can be divided into economic, political and social 
ones. Thus, economic integration refers to the merging of markets, social integration refers to the convergence and unification of societies, and political integration refers to the creation of a supranational state that reproduces the model of the "state in general" at its level, or the creation of a political community with a complex organized form of self-government (Baikov, 2010).

Euroregions also perform the functions of administrative and managerial coordination, institutional and spatial integration, and organizational identification of individual elements of the respective regions against the background of the existing significant differentiation of Ukraine and neighboring states whose territories are part of euroregions.

Euro-regional cooperation, which is one of the main elements of the EU's European integration strategy, ensures that the relevant regions are treated by the EU as a certain form of their involvement in the structure of a united Europe. Consequently, Euroregional initiatives received their support at the highest state level in Ukraine, since they served as a kind of political lever in the implementation of Ukraine's European integration aspirations.

The classical motives for the activation of Euroregions should be considered:

- the conscious desire of the heads of regional authorities and local self-government bodies of the border territories of Ukraine to institutionalize bilateral cooperation with their partners from the countries of Central and Eastern Europe in order to better use the potential advantages of the spatial development of the respective territories;

- the interest of representatives of public organizations, academia and other contact audiences in gaining access to financial resources allocated under the EU technical assistance programs for the implementation of infrastructure projects;

- an attempt to translate the main part of the initiatives in the humanitarian sphere into the channel of economic relations related to the growth of exports and imports of goods and services, attracting foreign investment, the development of transport infrastructure, which entails an increase in the economic potential of border areas and an increase in financial revenues to budgets of various levels.

The priority task for Ukraine in the field of international relations of Euroregional cooperation at the present stage is to improve and significantly increase the effectiveness of cooperation with the Central European countries-the new EU members. This is determined on the basis of the officially declared as the main strategic goal of Ukrainian foreign policy-the integration of Ukraine into the European Union. Interregional, cross-border cooperation in the new conditions can turn into an effective practical factor in the implementation of Ukraine's European integration plans. The strategic approach and program-targeted methods in the conditions of Ukraine's immediate neighborhood with the European Union create prerequisites for intensive production in the practice of cross-border relations, progressive and effective models of cooperation (Baikov, 2010).

In addition, at different stages of its existence, the Euroregion ensures the consistent passage of the next stages of the model of its formation (Mikula, 2004):

1) spatial and material structuring of the region;

2) development of regional consciousness;

3) institutional development of the region;

4) stabilization of the region.
Thus, the Euroregions formed on the border between Ukraine and the EU play a special role in the formation and development of cross-border regions. On the one hand, the nature of their functioning does not allow for the implementation of all the tasks that are assigned to the Euroregions in the EU states.

However, on the other hand, the Euroregions, which include the border territories of Ukraine, assume part of the functions of deepening foreign economic activity within the respective cross-border regions, which allows us to consider them as an important element of the institutionalization of foreign economic relations in these regions in the context of the European integration of Ukraine.

Methods and areas of implementation of integration processes in the Euroregions are presented in the Table 1.

The formation of regional policy in Ukraine according to European standards requires, first of all, the creation of an appropriate regulatory framework. Accession to the European legislative acts expands the legal field of euroregional cooperation, makes it possible to provide for the establishment of the responsibility of regional authorities for jointly adopted decisions, monitoring the implementation of measures arising from the agreements on cross-border cooperation concluded by the parties, and also extends the legal norms of the European Convention on Cross-Border Cooperation between Territorial Communities or authorities to cross-border cooperation. At the same time, in the practice of applying European documents, individual provisions are not always clearly interpreted.

Over the next 10 years (2020-2030) after the introduction of the free trade zone, Ukraine will implement a deep integration of the economy into the EU internal market, which provides for significant liberalization of trade in goods, services, capital flows, as well as a comprehensive harmonization of business rules with the EU norms. In accordance with the expectations of business, by liberalizing tariffs and bringing legislation closer to the European requirements, Ukraine will be able to take advantage of the new rules for lifting restrictions in this area.

In the approach to integration policy, the use of the features of the Euroregions that affect the improvement of the situation in the region is the new practice. The basics of supporting the innovation and integration economy of the Euroregion are united by network systems that create regional innovation systems.

Based on the functional and organizational view, the core of Euroregional systems is the activity that develops in the following directions (Mikula, 2004):

1. Development of innovation and entrepreneurship centers

- technology transfer centers;

- technology centers and parks, business incubators;

- technology information banks, patent offices.

2. Development of financing tools for a new form of innovative initiatives:

- risk mutual funds;

- credit and guarantee funds;

- subventions and payments to equalize the budget;

3. Support for entrepreneurship:

- organization of cooperation (clusters) between firms and scientific institutes;

- academic entrepreneurship and the education system aimed at entrepreneurship;

- implementation of pilot programs, competitions, and innovation exchanges. 
As an example, I would like to cite the Carpathian Euroregion. This is one of the main and highest-status institutional forms of cross-border cooperation between the regions of Ukraine and Hungary, in which the border regions of Poland, Slovakia and Romania also take part, and the first Euroregion that was founded in the Central European region (Table 2).

The Carpathian Euroregion was established as a coordinating body of the interregional association of authorities with the aim of improving the living conditions of the population in the border regions, stimulating the development of the economy of the peripheral regions and better developing cross-border cooperation across borders. As a model for developing cooperation between border regions, the Carpathian Euroregion was founded with the support of experts from the East-West Research Institute.

The Carpathian Euroregion is measured by European standards but the regions included in it are socially and economically peripheral in their countries, which is characterized by weak innovation potential and limited financial resources.

In the context of developing conceptual approaches to improving the effectiveness of cooperation within the Carpathian Euroregion, it is necessary to intensify interstate regional management in the direction of solving the problems of functioning of the Euroregional formation, taking into account the following guidelines:

1) unlocking the potential of the Carpathian Euroregion, comprehensively solving the tasks set, taking into account the fact that it is the catalyst for Ukraine's European integration aspirations, as well as the fact that there is an urgent problem of bringing the strategy of functioning of administrative units that are located in Ukraine with the general strategy of its state development in the direction of the need for Ukraine to join the European community;

2) coordination of the Ukrainian legislation regulating interstate cooperation within the framework of the Carpathian Euroregion and improvement of the institutional support, the process of developing a strategy for the development of territorial formation within the framework of the implementation of the norms and standards of the European Union;

3) creating favorable conditions for the Ukrainian side to join the interstate regional governance at the level of the Carpathian Euroregion, thus revealing its institutional potential and realizing Ukraine's ability to carry out fullfledged international interregional cooperation within the framework of this territorial formation by actively participating in international programs and projects and ensuring the representation of the regions in their development;

4) coordination of the work of government representatives, business structures and institutions-public organizations, which concerns the planning of a strategy for the development of cooperation at the level of the Carpathian Euroregion, which has both cross-border and interregional, and its own cross-border directions, which will lead to an improvement in the management process at the level of Euroregional education in the context of solving common economic, social, energy and environmental problems for the participating countries and improving interaction between them.

These guidelines should guide the transition of the Carpathian Euroregion to a qualitatively new level of its functioning and more widely involve the public in

TABLE 1 Methods and areas of implementation of integration processes in Euroregions

\begin{tabular}{|c|c|}
\hline $\begin{array}{l}\text { Methods of } \\
\text { implementation of } \\
\text { integration processes }\end{array}$ & Areas of implementation of integration processes \\
\hline Organizational & $\begin{array}{l}\text { - continuous international cooperation of regional and local self-government bodies on both sides of the border; } \\
\text { - establishment of cross-border organizations with a permanent secretariat and experts and administrative staff; } \\
\text { - creation of private foundations based on interstate agreements }\end{array}$ \\
\hline The work of the Euroregion & $\begin{array}{l}\text {-development and strategic oriented cooperation, cross-border nature, where partnerships at the vertical (European, } \\
\text { governmental, regional) and horizontal (creating spheres of activity implementation cross-border solutions at the } \\
\text { national level in accordance with procedures acceptable to all parties to avoid conflicts; the joint participation of } \\
\text { citizens, institutions and the social partners in programs, projects, and key processes), allowing to create new points of } \\
\text { economic growth of regions on both sides of the border; } \\
\text { - direct initiatives and the use of their own resources as a prerequisite for obtaining assistance and support from third } \\
\text { parties }\end{array}$ \\
\hline Cross-border cooperation & $\begin{array}{l}\text { - defining the field of action in accordance with common interests (for example, infrastructure, economy, culture); } \\
\text { - equal emphasis in social and cultural cooperation and economic and infrastructural cooperation; } \\
\text { - implementation of agreements and arrangements concluded at the European level between countries to achieve cross- } \\
\text { - consultation, assistance and coordination of cross-border cooperation, in particular in the following areas: economic } \\
\text { development, transport and traffic, regional development, environmental protection and nature conservation, culture } \\
\text { and sports, recreational activities, energy, waste management, tourism and recreation, agricultural development, } \\
\text { education, social cooperation, rescue and disaster prevention services, communications, public safety }\end{array}$ \\
\hline
\end{tabular}

TABLE 2 Basic information about the members of the Carpathian Euroregion as of 01.01.2021

\begin{tabular}{|c|c|c|c|}
\hline Member Country & Region & Population & Area $\mathbf{k m}^{2}$ \\
\hline Poland & Subcarpathian Voivodship & 2127462 & 17845,66 \\
\hline Romania & Satu Mare, Maramureș, Bihor, Suceava, Botoșani, Sălaj, Harghita counties & 2616000 & 28639 \\
\hline Slovakia & Košice and Prešov regions & 1554740 & 10459 \\
\hline Ukraine & Zakarpattia, Ivano-Frankivsk, Lviv and Chernivtsi regions & 6429900 & 56660 \\
\hline Hungary & Borsod-Abaúj-Zemplén, Hajdú-Bihar, Heves, Jász-Nagykun-Szolnok, Szabolcs-Szatmár-Bereg regions & 2616000 & 28639 \\
\hline
\end{tabular}


cooperation within its borders. In particular, in the field of interstate regional management, it is necessary to implement such measures that will improve the results of the activities of this formation:

- the creation of an executive body that can be represented by a public organization, which will open the possibility for the national office to actively work on the model of national offices of euroregions in Eastern European countries and provide practical advice to management bodies;

- a clear definition of the framework of cooperation between the countries participating in Euroregional cooperation and the identification of promising sources of financing for such cooperation;

- improving the quality of communication between the participants of the Carpathian Euroregion in order to improve the exchange of business information in order to improve the interaction of management bodies with business structures and to obtain the data necessary to improve the work of the interstate formation itself;

- introduction of the practice of clustering within the Carpathian Euroregion, which will allow to respond quickly to changes in the world market conditions and contribute to the implementation of the functioning of the euroregion by taking into account the competitive advantages of the subjects belonging to the composition of this region.

\section{Innovative forms of Euroregional development as a process of integration}

The introduction of new forms of Euroregional cooperation (clusters, cross-border cooperation, Euroregional innovation projects, industrial parks and zones, cross-border trade) not only improves the mechanism for ensuring the competitiveness of border territories, eliminates the existing problems of cross-border cooperation but also expands opportunities (provided that an appropriate legal framework is created), which changes the vision of the essence of Euroregional cooperation.

State programs and projects related to the allocation of productive forces, as well as the solution of social problems, can become the subject of competition between regional entities. With a constant shortage of resources, only those regions with a high level of reliability of competitive positions will be able to apply for participation in the implementation of such programs and projects.

The competitiveness of regions depends on the ability to innovate, modernize production and technological processes, and adapt to changing environmental conditions. In modern conditions, the competitive economic position of regional economic entities is determined by their ability to carry out economic activities in a market environment in conditions of independence and self-financing. This fundamentally new phenomenon deeply permeates all spheres of activity of enterprises and organizations, their competitiveness can be defined as a potential opportunity to occupy a corresponding niche in the market of goods and services that provide the subject of market relations with a stable financial and economic position.

In the current conditions of the development of integration processes in Ukraine, cross-border cooperation has the opportunity to accelerate the processes of equalizing the quality of life of the population of the Euroregions to the Central European one and to promote the free movement of goods, people and capital across the border. It also helps mobilize local resources and increase the efficiency of their use, and provides opportunities for joining efforts to solve common problems in a cross-border region. Cross-border cooperation plays an important role as a "testing ground" for testing and adapting European legislation, a tool for increasing the role of adaptation regions and financial support mechanisms.

Taking into account the priority goals of Ukraine (rapprochement of relations with the EU and further accession to the economic Union), an important element of economic integration is the further convergence of its regional policy in order to clearly identify the place and role of domestic regions in the European model "Europe of Regions", which provides for:

1. Administrative and territorial reform, which will make it possible to distinguish the NUTS-2 (region) and NUTS-3 (districts) levels, which will indicate their European territorial hierarchy. This will make it possible to receive financial assistance from the EU structural funds.

2. Implementation of European regional development mechanisms and instruments (investments, subsidies).

3. Development of Euroregional and cross-border cooperation.

4. Creation of independent conditions for innovative development of regions (Kovalenko, 2013).

In this context, it is important to develop regional cooperation, in the field of Euroregions and cross-border cooperation, and in the new geopolitical situation, the authorities should give the regions a new mission in the state. Ukraine's direct proximity to the EU countries (land or sea) opens up the border areas not only opens up access to the EU markets and funds, but also makes it possible to assume the role of the "south-western vector" of Ukraine's integration into the EU.

In this context, the impact of the transnationalization of the economy (capital movement) on the development of Euroregions and the formation of appropriate regional policies deserves special attention. This impact on the economy of the regions of Ukraine is ambiguous. On the one hand, the placement of capital is seen as the expectation of strategic investors, on the other hand, there are differences between private and multinational investments.

The transnationalization of the regional economy should be considered as the process of the entry of transnational capital into the regional economy and the creation of conditions for the formation of domestic integrated industrial and financial groups in order to optimize the structure of the regional economy and use their functions for synergy (methodological principles) to solve various problems in regional development. To achieve this goal, it is necessary to improve the state regional policy, which should contain a set of measures to protect the economic security of the regions and guarantee support for the defense of their interests in international regulatory structures.

New commercial transnational connections of regional systems, firms, taking into account the globalization processes, transformations in the national economy, tend to build regional policy, to approach the traditional vertical in a new way: the enterprise economy - the regional economy - the national economy - the world economy; to influence the factor conditions that determine the competitive advantages of the region, the conditions for the interaction of industries, socio-economic and political conditions. It is the factor conditions that most determine the competitive 
advantages of the region and accelerate or slow down transnational processes.

The processes of transnationalization of the economy of the regions of Ukraine should be regulated by means of regional policy. The essence of this policy is the measures implemented by the state in the person of regional authorities to obtain positive synergistic effects of interaction for the formation of innovative and investment development and economic security of the regions. The undesirable impact of transnationalization activities on the development of the country's regions is a problem of a specific territory, so regional authorities should have levers of influence on the results of such activities, reflected in the modern concept of state regional policy under the conditions of the formation of a legislative framework for regulating the processes of the regional economy at the state level.

An important factor in the implementation of the innovation and investment model of Euroregional development is the creation of scientific and technological structures of technoparks, cross-border cluster. The modern technopark is considered as a form of territorial integration of science, education and production in the form of an association of scientific organizations, design bureaus, educational institutions, manufacturing enterprises or their divisions in order to accelerate the development and implementation of scientific, technical and technological achievements. It is technology parks that can become organizational structures where fundamental and applied scientific research is put into practice, and favorable conditions are created for scientists, engineers and inventors to implement new ideas and inventions. Technology parks also contribute to solving social problems of the territory's development, as new jobs appear, the quality of social infrastructure improves, the income of the population increases, and favorable conditions are created for the activation of investment activities.

At the same time, there are still other auxiliary tools for improving the innovation of border regions in the context of euroregional cooperation. In Table 3 the characteristics of additional extension tools are given innovation of border territories in terms of euroregional cooperation.

Regional investment programs should be comprehensive. In a limited unity with a focus on the development of individual industries and small businesses, the program should provide for improving the condition of roads and telecommunications, which mainly determines theinvestment attractiveness of the region for investment. Programs should include the development of social infrastructure to increase the competitiveness of the population in the labor market. Another important point is that regional investment programs define the so-called poles.

The basis of clustering within the euroregions is the creation of scientific, technical and logistics clusters. The scientific and technical cluster is understood as an organizational structure that includes research institutes, higher educational institutions and enterprises, where scientific and technical developments of the scientific and technical cluster will be implemented, which will solve the issues of updating the material and technical base of scientific institutions and higher educational institutions, increase the share of innovative and active enterprises, increase the knowledge intensity of GDP, create new jobs and improve the export potential of states. Scientific and technical clusters can be developed on the basis of existing technoparks.

In this case, the euroregional cluster is considered as an organization of geographically interconnected and complementary enterprises located on both sides of the border (including specialized suppliers, in particular service providers, as well as manufacturers and buyers), united around a research and innovation center, which is connected by vertical links with local authorities to increase the competitiveness of enterprises, regions and the national economy (Mikula, 2004).

As for euroregional business incubators, this activity is currently in at its roots. According to statistics, 76 business incubators operate in Ukraine. In fact, there are no more than 10 effective ones, and there are no euroregional ones at all. To date, only one business incubator is known in the city of Rezina (Moldova, Euroregion "Dniester").

In conclusion, I would like to say that the priorities of the state euroregional policy should be to stimulate and support local initiatives to effectively use the internal potential of the regions to create and maintain a fullfledged living environment, improve the quality of life of people; reduce territorial differentiation according to the regional human development index; form the competitiveness of regions through the development and implementation of programs and projects to improve the competitiveness of territories; improvement of material, financial, information, personnel and other resource support for the development of regions, assistance in the exercise of powers by local self-government bodies.

In order to determine the most favorable organizational forms of euroregional cooperation, a

TABLE 3 Additional tools for increasing the innovation of border territories in the context of euroregional cooperation

\begin{tabular}{|c|c|c|}
\hline Additional tool & Characteristics & Application options in Ukraine \\
\hline $\begin{array}{l}\text { Public-private } \\
\text { partnership }\end{array}$ & $\begin{array}{l}\text { Public-private partnership is the cooperation between } \\
\text { Ukraine, the Autonomous Republic of Crimea, territorial } \\
\text { communities represented by relevant state bodies and local } \\
\text { self-government bodies (state partners) and legal entities, } \\
\text { except for state and municipal enterprises, or individual } \\
\text { entrepreneurs (private partners), carried out on the basis of } \\
\text { a contract in accordance with the procedure established by } \\
\text { this law and other legislative acts. }\end{array}$ & $\begin{array}{l}\text { Project implementation in Ukraine's public-private partnerships } \\
\text { provided only exclusively in the form of an agreement, whereas in } \\
\text { most European countries there is no such restriction. } \\
\text { Accordingly for the implementation of possible conclusions } \\
\text { of cooperation such agreements: concessions, joint activities, } \\
\text { distribution products and others. At the same time, type of } \\
\text { contract concluded in the framework of cooperation is defined by } \\
\text { the decision-making body about its implementation }\end{array}$ \\
\hline $\begin{array}{l}\text { European countries } \\
\text { grouping territorial } \\
\text { cooperation }\end{array}$ & $\begin{array}{l}\text { This type of partnership is a group created with the purpose } \\
\text { of facilitating cross-border cooperation between the } \\
\text { members of the European Union in order to strengthen the } \\
\text { economic and social sphere social unity }\end{array}$ & $\begin{array}{l}\text { This type of partnership is being expanded by new companies' } \\
\text { cross-border opportunities for cooperation and for border guards } \\
\text { regions of Ukraine in connection with ratification of Protocol No. } \\
3 \text { by the Verkhovna Rada of Ukraine to the European framework } \\
\text { CBC conventions. }\end{array}$ \\
\hline
\end{tabular}


procedure for justifying the choice of forms of innovation and investment cooperation should be developed. It is proved that a promising form of cooperation that opens up new opportunities for expanding euroregional cooperation is business incubators, cluster associations of enterprises (group of enterprises), i.e. a contractual association of two or more individuals or legal entities in order to promote the development of the economic activities of its members and/or make a profit for each of them/group.

\section{Conclusions}

The development of Euroregional cooperation in the innovation sphere and its effectiveness is determined by the capabilities of a particular region, taking into account the chosen model of innovative development, which is formed under the influence of a number of factors: the level of socio-economic development of the region, the state of development of innovation infrastructure, human resources in the innovation sphere, the availability of financial resources for innovation, the innovation policy of local authorities, the degree of state influence on innovation processes in the region. The interrelation of these factors determines the opportunities for the development of Euroregional cooperation in the field of innovation, as well as ways to overcome the problems that stand in the way of activating the innovation activity of the regions of Ukraine.

To date, the euroregional relations between Ukraine and the EU are not burdened with problems and claims of a political and economic nature. Therefore, the interaction of Ukraine and the EU in the field of euroregional and crossborder cooperation can be more dynamic and effective than at the interstate level.

Formation of economically competitive Euroregions, creation of joint associations and projects with the EU, creation of new agreements to update the legal framework for cooperation, coordination of socio-economic and environmental development of the Euroregion territories.

Substantiation and implementation of the conceptual foundations of the theory and practice of Euro-regional cooperation of Ukraine are:

1. Better understanding of the prospects for Euroregional, cluster and cross-border cooperation between Ukraine and the EU.

2. Implementation of the main principles of the EU regional policy in the national legislation of Ukraine.

3. Creation of the appropriate infrastructure for the regulation of the Euro-regional policy of Ukraine, as a harmonization of the territorial division, taking into account the specifics of the territorial structure of Ukraine.

\section{References}

[1] Baikov, A. (2010). Bibliografiya sravnitelnoy integratsii v 2000-h godah [Bibliography of Comparative Integration in the 2000s]. International Processes, 1, 58-73. (in Russian)

[2] Oleksandr Borkovski, Mihal Klepka, Kshishtof Matusyak, Ezhi Stshelts (2005). Instrumenti pidtrimki innovatsiynosti malih i serednih pidpriemstv: dosvid Polschi ta Evropeyskogo Soyuzu [Tools for supporting innovation in small and mediumsized enterprises: the experience of Poland and the European Union]. Poznan / Kyiv. (in Ukrainian)

[3] Mikula, N. (2004). Mizhterytorialne ta transkordonne spivrobitnytstvo: monohrafiia [Inter-territorial and cross-border cooperation]. Lviv: IRD NANU. (in Ukrainian)

[4] Rehionalna polityka ta rozvytok mistsevoho samovriaduvannia [Regional policy and development of local selfgovernment]. E-source: http://old.niss.gov.ua/book/DOPOVID07/Dopovid-Rozd-6.pdf (accessed 15 May 2021).

[5] Kovalenko, S. I. (2013). Evroregion «Nizhniy Dunay»: perspektivy razvitiya innovatsionnyih form transgranichnoy kooperatsii v usloviyah rasshireniya ES [Euroregion "Lower Danube": prospects for development of innovative forms of cross-border cooperation in the EU enlargement]. (in Russian)

[6] Mikula, N. (2004). Stratehiia formuvannia ta pidtrymky rozvytku transkordonnykh klasteriv. Sotsi-al'no-ekonomichni problemy suchasnoho periodu Ukrainy. Klastery ta konkurentospromozhnist' prykordonnykh rehioniv [Strategy for forming and supporting the development of cross-border clusters. Social and economic problems of the modern period of Ukraine. Clusters and competitiveness of border regions]. Lviv: IRD NANU. (in Ukrainian) 